\title{
THE LEIDEN LEGACY: CONCEPTS OF LAW IN INDONESIA
}

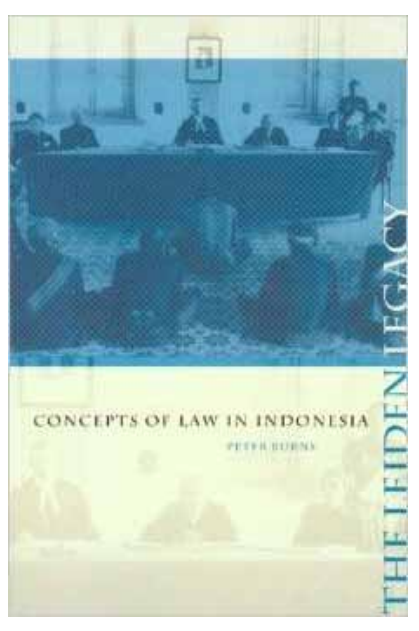
on legal analysis from above. Indonesian contemporary literature that systematically investigates debate over legal unification versus legal pluralism is surprisingly thin. The uncritical attitude toward the legal system as colonial legacy continues to persist among Indonesian legal academia and practitioners. Systematic efforts in identifying the problem in Indonesia's legal system ironically come from Western scholars such as Adriaan Bedner, ${ }^{3}$ Sebastiaan Pompe, ${ }^{4}$ and Dan S. Lev. ${ }^{5}$

Against this backdrop, Peter Burns's book entitled The Leiden Legacy: Concepts of

\footnotetext{
${ }^{1}$ Jamie Davidson and David Henley (eds), The Revival of Tradition in Indonesian Politics: The Deployment of Adat from Colonialism to Indigenism, Routledge Contemporary Southeast Asia Series: 2012.

${ }^{2}$ Adat literally means customs or traditions. In the legal discourse, Adat generally can be defined as sets of principles and values as well as local wisdoms that are embedded in the society. Adat including Adat Law have been integral parts of indigenous social orders that serve to create and to maintain peace and harmony within the society.

${ }^{3}$ See for example: Bedner A.W. (2013), Indonesian Legal Scholarship and Jurisprudence as an Obstacle for Transplanting Legal Institutions, Hague Journal on the Rule of Law 5(2): 253-273; Bedner A.W and Stijn van Huis, "the Return of the Native in Indonesian Law: Indigenous Communities in Indonesian Legislation," Bijdragen tot de Taal-, Land-en Volkenkunde (BKI) 165-2/3 (2008).

${ }^{4}$ Pompe's work includes The Indonesian Supreme Court: A Study of Institutional Collapse (Southeast Asia Program Publications: 2005).

${ }^{5}$ Dan S. Lev, for example, has been a consistent proponent of an interdisciplinary approach to legal studies. He critically examines the history of the Indonesian legal system through the lens of real politics, in which power plays a dynamic role over the course of the development of legal institutions. This analytical stance can be seen in his essays on various legal issues, see: Daniel S. Lev, Legal Evolution and Political Authority in Indonesia: Selected Essays, (London-Leiden Series on Law, Administration, and Development, 4, London: Springer, 2000).
} 
Law in Indonesia serves as an important contribution to fill the gap in the Indonesian legal literature pertaining to adat law and Indonesian legal system. This book provides a historical account for the concept of Indonesian law, focused particularly on the development of the idea of adat law and its place within the national legal system. Main issue addressed by the book concerns the half-hearted acceptance of adat law that continues to become a problem up to this date.

Despite facing repression under the new order regime as well as challenge from modernity and globalization, adat institutions have not perished. Instead, they continue to be one of the primary sources of law and provide an important informal mechanism of conflict management at the local level. The persistence of adat particularly in the outer islands shows that national law never fully supersedes adat. Instead, as Dinnen notes adat has proved remarkably resilient and continues to "adapt to the local and external dynamics of social change." ${ }^{6}$

Although at the local level people are inclined to use adatinstitutions as the primary legal source and show less reliance on the state-centered law, adat receives limited recognition at the national level. Adat and legal pluralism to some extent are seen as a potential threat to the national unity and stability. The Indonesian Constitutions and later amendments recognize adat laws provided that they still exist in the society and do not contravene the state law. Government policies are bent toward the unification of the legal system, abandoning legal pluralism in the society and leaving adat institutions at the periphery. The role of national law was strengthened at the cost of adat law. ${ }^{7}$

Peter Burns tracks the problem of the recognition of adat law back to the formulation of the colonial constitution in the early $19^{\text {th }}$ century. His book is a Weberian in nature in the sense that he views ideas as a central force in the course of the history. In this regard, Burns views the concept of adat yield a major contribution in shaping Indonesian identity and nationhood. However this very concept of adat is actually a product of rationalization of the Indonesian culture, including legal values and norms, by the Dutch.

Contrary to common belief, Burns argues that the conventional distinction between the East and the West is a false dichotomy. He argues that adat as an independent body of legal system with its distinctive nature is a myth. The concept of adat law originates from the theories of Post-Enlightenment in Central Europe, brought to the Dutch East Indies by the Leiden School. The ideas of the Leiden School were vindicated in Indonesia's independence when adat was accepted as a national identity for the new republic. As Burns says,

"I argue in fact for an irony. Indonesians struggled hard to disengage their country from the Netherlands. They struggle long to establish its identity. Yet that identity was informed by ideas more Dutch, in origin, that aboriginal. And the identity was conceived in terms derived from Central Europe." (p. xv)

Burns then suggests a new interpretation of adat law for adat has been an ideological anomaly in independent Indonesia. Adat is recognized by the law, but does

${ }^{6}$ Sinclair Dinnen for UNICEF Papua New Guinea, “'Traditional' Justice Systems in the Pacific, Indonesia, and Timor-Leste," April 2009, accessed through: http://www.unicef.org/tdad/index 56512.html, p.2.

${ }^{7}$ Sebastiaan Pompe (b), "Between Crime and Custom: Extra-marital Sex in Modern Indonesian Law," in Tim Lindsey, Indonesia, Law and Society, 2nd Edition, (The Federation Press, 2008), p. 106. 
not really matter in practice. Burn argues that Adat brings about repercussions that its original exponents did not intend because the theory was flawed and the practice ignored. This leads to the increasing phenomenon of forum shopping as one of the solutions to resolve the theoretical problems of legal pluralism.

The book is organized into two sections. The first section entitled "Making the Myth" addresses the history of the concept of adat law, which Burns refers as the "myth." In this section, Burns allocates a great amount of time tracing the development of the concept of adat, exclusively from the writings of Van Vollenhoven.

Burns views Vollenhoven as the key agency in the struggle of the formulation of legal framework for the Dutch East Indies (later Indonesia) back in early $19^{\text {th }}$ century. The first three chapters of the book thus provide a historical narrative of the debate between legal codification and the recognition of indigenous rights in the colonial constitutions (het Regeeringsreglement van Nederlandsch-Indie). Vollenhoven was a persistent opponent of legal codification and very strong proponent of legal pluralism, and particularly the application of adat law (adatrecht) in private realm. In fact, he was the pioneer of the field adat law studies that was often identified as "the Leiden School." Vollenhoven was then nicknamed the Father of Adat Law for his compassionate efforts for the legal and political recognitions of adat law, albeit visited Indonesia for only twice in total. ${ }^{8}$

In the following chapter, Burns lies out the debate of the recognition of indigenous rights in the field of land rights. In the next three chapters, Burn elaborates "the Leiden Doctrines" concerning the concept and the application of adat law in the fields of criminal law, family law, and procedural law. The Leiden School eventually gained victory in 1927 with the recognition of adat law operates as an independent set of rules for the natives Indonesian.

Having set the stage for making the myth, Burns turns to the second section of the book entitled "Dismantling the Myth." This section focuses to debunk the myth of adat and its repercussion on the Indonesian legal system. It begins with criticism posed by the members of faculty of law at Utrecht University that challenges the validity of the Leiden doctrines. The Utrecht School casts serious doubt on key ideas of the Leiden doctrines particularly on the arguably distinctive nature of adat law.

In the later chapter, Burns provides an analysis on the European roots of Indonesian nationhood and examines the relationship among custom, law, and colonialism. Burns shows that the idea of adat law steams from European post-enlightenment doctrine of law, which treats local convention as a symbol of a distinctive ethic identity. In this regard, the idea of adat strengthens ethic identity and communal bonds, which in turn help to shape national identity and self-consciousness among Indonesians.

In general, this book offers an insightful account on the struggle between legal pluralism and legal codification. The recognition and the application of adat has been a subject of theoretical and administrative debates for decades. This issue becomes particularly apparent following the demise of Suharto's new order regime in 1998.

Nevertheless, Adat remains irrelevant for it continues to be treated as ancient laws; a peculiar sets of norms that are unable to cope with modern development. Adat law is often associated with backwardness characterizing traditional societies as opposed

\footnotetext{
${ }^{8}$ See: Leiden University, “Cornelis van Vollenhoven (1874-1933)," A translation of G. van den Steenhoven, 'Vollenhoven, Cornelis van (1874-1933)', in Biografisch Woordenboek van Nederland, accessed through: media.leidenuniv.nl/.../Cornelis\%20van\%20Vollenhoven\%20ENG.pdf.
} 
to modern ones. It is thus seen as a remnant of the past that lingers despite countless efforts for "modernization." I call this a fossilization of Adat for it is learned as gaib, a static phenomenon in a textbook, instead of as a dynamic living legal system in society. Adat is reduced to morality (norma kesusilaan) at best, without any practical necessity for a legal and policy framework.

This problem can be attributed, partly, to the legal education system and the way of teaching adat law. Adat is taught as if it was a coherent and unitary set of rules in a particular traditional community. However, Adat law is a diverse and dynamic system. In fact, there is no single or uniform type of Adat in Indonesia; which reflects ethnic diversity that characterizes the country. In addition, contrary to common perception, Adat is a dynamic institution for it constantly adapts to change and evolves over time. Flexibility is an inherent nature of Adat as it develops in parallel with the development of the society in which it operates. ${ }^{9}$

So long as there is no massive reform in legal education, no radical change in the bureaucratic attitude of legal scholars, and no transformation toward the interdisciplinary approach of law, the inherited Civil law tradition and all of its problems will continue to be taken for granted without any serious evaluation. Accordingly, Adat law will continue to be treated as a fossil of the past with no significant influence in the policy making process, and justice will remain remote and unattainable for the common people.

Title : The Leiden Legacy: Concepts of Law in Indonesia

Language : English

Publisher : KITLV

Author : Peter Burns

Pages : 269

Year : 2004

Reviewer : M. Yahdi Salampessy, S.H., M.H.

\section{Bibliography}

Bedner, A.W. "Indonesian Legal Scholarship and Jurisprudence as an Obstacle for Transplanting Legal Institutions," Hague Journal on the Rule of Law 5(2): 253273 (2013).

and Stijn van Huis. "The Return of the Native in Indonesian Law: Indigenous Communities in Indonesian Legislation," Bijdragen tot de Taal-, Land-en Volkenkunde (BKI) 165-2/3 (2008).

Davidson, Jamie and David Henley (eds). The Revival of Tradition in Indonesian Politics: The Deployment of Adat from Colonialism to Indigenism. Routledge Contemporary Southeast Asia Series: 2012.

Dinnen, Sinclair. “'Traditional' Justice Systems in the Pacific, Indonesia, and TimorLeste," UNICEF Papua New Guinea, April 2009. Accessed through: http://www. unicef.org/tdad/index 56512.html.

\footnotetext{
${ }^{9}$ Najmu L. Sopian, “Informal Dispute Resolution Based on Adat: Case Study: Land Dispute at the District of Soa, Ngada Regency, Flores, Indonesia,” unpublished paper.
} 